\title{
Iranian Common Attitude Toward Opium Consumption
}

\author{
Mehran Zarghami ${ }^{1, *}$ \\ ${ }^{1}$ Department of Psychiatry School of Medicine Mazandaran University of Medical Sciences, AND Psychiatry and Behavioral Sciences research Center, Addiction Institute, \\ Mazandaran University of Medical Sciences, Sari, IR Iran \\ ${ }^{*}$ Corresponding author: Mehran Zarghami, Zare Hospital, Taravat Street, Neka Road, Sari, Mazandaran, IR Iran. Postal code: 4843185774. Tel: +981133273024, Fax: +981133285109, \\ E-mail: mzarghami@mazums.ac.ir
}

Received: January 8, 2015; Revised: April 28, 2015; Accepted: May 5, 2015

Iran is suffering from the $2^{\text {nd }}$ most severe addiction to opioids in the world. While the explanation of this enormous drug problem is refutably related to drug trafficking, the drug dilemma also illustrates the chain reaction of the imposed war with Iraq in 1980 - 88 ; the problems of poverty, unemployment, urbanization, homelessness, adultery, family crises, divorce, domestic violence, and runaway children. Although opium addiction often linked to these factors, drug use is common among all social classes. It seems that a positive traditional attitude is another reason for widespread raw opium use in this country. A survey in Iranian literature reveals that famous Iranian poets, who have a substantial contribution on cultural attitude formation of Iranian population, have used the phrase "Teriac" (raw opium) as a means of "antidote" a substance that treats every disease. It seems that a concrete deduction from the literature has been leaden to a positive attitude towards opium consumption in Persian culture. Recent research also supports this idea. Many patients use raw opium as a pain killer or for treating hyperlipidemia, hypertension, diabetes and other chronic diseases; most of them had started the use after developing the disease and the remaining had increased the consumption after developing the disease. Regarding this superstitious common belief, drug control headquarters should focus on education and correction of the faulty unhealthy attitude toward opium consumption.

Keywords: Attitude; Iran; Opium

The exact origin of opium poppy is uncertain (1). The "land of the civilized kings"(Sumer), in the southernmost region of ancient Mesopotamia (modern-day Iraq and Kuwait) which is generally considered the mother of civilization has been hypothesized as the origin of this plant in more than 5000 years ago (2). Assyria, the major Mesopotamian East Semitic Kingdom, in the north of Sumer, and the Ancient Egypt, in south west neighborhood of Sumer began to grow and process opium then. These regions formed a part of the great Iran Empire territory, a larger region also called Persian Empire in the Western world, comprising the area from the Eurasian Steppe and over the Middle East area, especially the whole part of the Persian Gulf and some parts of the Arabian Peninsula (3, 4 ), including islands of this region and the Gulf of Oman in the south, and from Egypt and Anatolia in the west to the borders of Ancient India, Indus river and Syr Darya in the east (5). Opium poppy cultivation spread along the Silk Road through this empire and reached to Afghanistan, which is the greatest illicit opium producer in the entire world now (2).

"Hul Gil" which means "joy plant" was the first name of Papaver somniferum; the species of plant from which opium and poppy seeds are derived (2). Dioscorides was the first known scientist who discussed the recreational properties of opium in his book; Do Materia Medica (1). It has been documented over the centuries that Afiyun (broken words Opium) is a tranquilizer and hypnotic (6). Abu Bakr Mohammad Ibn Zakariya Razi (864 - 930 CE) described the chemical properties of this substance. He was the first surgeon who used opium for anesthesia (7). Abu 'Ali al-Husayn Ibn-Sina (Avicenna), the other Iranian scientist (980 - $1037 \mathrm{AD}$ ) realized that opium is addictive and only recommended it temporarily to eliminate pain, diarrhea and "eyesore" (8).

Opium consumption gradually became prevalent in Iran, and this region became the scene of traditional opium poppy cultivation from $15^{\text {th }}$ century Safavids' empire (and presumably before too) (9). Opium smoking was a part of recreational activities of upper social class. However, social adversities may be the main reason of gradual widespread opium usage as a tranquilizer in demos at that time. Practically, the processed opium was for indigenous smoking and eating in the entire region (10).

Nowadays, raw opium is the most prevalent substance of abuse in this country. According to the United Nations' office on Drugs and Crime (UNODC) Iran is suffering from the $2^{\text {nd }}$ most severe addiction to opioids (11), and the highest rate of heroin and opium addiction per head of population in the world. $20 \%$ of the Iranian population aged 15 - 60 is taking part in drug abuse, and one in 17 is a regular user (12). The annual opium consumption in Iran is 450 metric tons, UNODC estimates (13). Other statistics indicate that more than 4 million of Iran's 70 million peo-

Copyright ( 2015, Mazandaran University of Medical Sciences. This is an open-access article distributed under the terms of the Creative Commons Attribution-NonCommercial 4.0 International License (http://creativecommons.org/licenses/by-nc/4.0/) which permits copy and redistribute the material just in noncommercial usages, provided the original work is properly cited. 
ple are addicted to substances (12); $69 \%$ to $94.6 \%$ of whom are dependent to raw opium $(10,14,15)$, and about $83 \%$ of Iranian opioid dependent individuals who sought treatment services in 2009 were addicted to opium (16). The reliability of the prevalence of addiction is doubtful, but even the more conservative measures are notably high.

While the explanation of Iran's enormous drug problem is refutably related to drug trafficking, since the mid1990, state officials and professionals have identified that addiction is prevalent for a number of social reasons. In these explanations the drug dilemma illustrates the chain reaction of the imposed war with Iraq in 1980 - 88; the problems of poverty, unemployment, urbanization, homelessness, adultery, family crises, divorce, domestic violence, and runaway children. Although opium addiction often linked to these factors, the addiction cuts across all ages and social, educational and economic class barriers (12). Many experts believe that Middle-aged professionals and scholars are as exposed to the possibility of being attacked or harmed, either physically or emotionally, as illiterate or under-educated, poverty-stricken youth. Observing the demos behavior, it seems that a positive traditional attitude is another reason for widespread raw opium use in Iran.

A survey in Persian literature reveals that famous Iranian poets who have a substantial contribution on cultural attitude formation of Iranian population, and may be regarded as being the cornerstones of the Iranian culture, such as Abu Najm Ahmad ibn Ahmad ibn Qaus Manuchehri Damghani (died 1040 CE), Hakim Abul-Qasim Ferdowsi Tusi (940 - 1020 CE), Abu Mansur Ali ibn Ahmad Asadi Tusi (999/1000 - 1072/1073 CE), Abu Mo'in Hamid ad-Din Nasir ibn Khusraw al-Qubadiani or Nasir Khusraw Qubadiyani (1004 - 1088 CE), Ghiyath adDin Abu'l-Fath 'Umar ibn Ibrahim al-Khayyam Nishapuri (1048 - 1131 CE), Hakim Abul-Majd Majdud ibn Adam Sana'i Ghaznavi (1080 - 1131/1141 CE), Hakim Soozani-Samarghandi (1800 CE), Afzaladdin Badil (Ibrahim) ibn Ali NadjarKhaqani (1121/22 - 1190 CE), Nizami Ganjavi (1141 - 1209 CE), Abu Hamid bin Abu Bakr Ibrahim, better known by his pen-names Farid ud-Din and Atțar of Nishapur (1145 - 1220 CE), Abu-Muhammad Muslih al-Din bin Abdallah Shirazi, Saadi Shirazi (1210-1291/92 CE), Khwaja Shams-ud-Din Muhammad Hafez-e Shirazi (1325/26 - 1389/90 CE) and Bagher Kashi $\left(16^{\text {th }}\right.$ century) have used the phrase "Teriac" (raw opium) as a means of "antidote", a substance that treats every disease (17). For example, Hafez, the famous Iranian poet who has an influential effect on the Iranian culture formation says: "If you hurt me, it would be better than that others medicate me; If you poison me, it would be better than that others give me opium", and Saadi the other Iranian popular poet says, "Poison will kill where there is no opium". Ferdowsi, who is well-known as the regenerator of the Persian language, believes that "The ultimate bed is nothing other than soil; the final gain in the world is poison, not opium". "If your nature is clear and clean, you would be as opium for her in lieu of poison", Khaqani says. Nasir Khusraw resembles justice as opium and injustice as poison, and Manuchehri Damghani says "Opium is great, and the cure of all sorrowing". Attar, who had an immense and lasting influence on Persian poetry and Sufism, mentions "Your love killed me; Give me some opium on time" (17). Khayyam in one of his quatrains compares the world's sorrows to poison, and equates its antidote which is opium with wine (Spring's arrival and winter's departure turn, The pages of our lives incessantly. Drink wine and do not worry, for the sage said: "Worldly sorrows are poisons and wine is their opium") (18). It seems that a concrete deduction from the literature has been leaden to a positive attitude towards opium consumption in Iranian culture. Besides, some old medicine sources believe that opium is a substitute treatment of chronic diseases such as cardiovascular diseases, hypertension and diabetes mellitus (19).

Recent research also supports this idea. These studies indicate that the prevalence of opium consumption is rising in patients with chronic diseases, mostly those with less awareness about the addictive properties and side effects of this substance $(19,20)$. In a study performed on the elderly patients hospitalized in the cardiology ward, reasons of opium use were evaluated based on patients' point of view. In this study, $16.3 \%$ of patients were addicted to opium; $33 \%$ of the opium dependent patients used opium as a pain killer and the rest used it for treating hyperlipidemia, hypertension, diabetes and other chronic diseases (21). In another study on diabetic patients, $10.9 \%$ of them were currently using opium. Amongst them, 63.6\% had started the use after developing the disease; the rest of them had increased the consumption after developing the disease. $72 \%$ of these patients were advised by others to use opium for treating diabetes mellitus. The researchers have concluded that the target population of opium users may change following the development of chronic diseases (22). The benefits for which the raw opium has been used, at least initially, such as antidiarrheal, pain relief, and tranquilizing effects which are sometimes referred as refreshment and physical and mental rehabilitation, potentiates traditional positive beliefs regarding opium.

The effect of opium especially in diabetes mellitus, hypertension and cardiovascular diseases control which is the focus of many other studies in Iran (19, 23-30), emphasize the importance of this popular believe in this topic. Some authors believe that the continual role of opiates as folk medicine constructs a genuine question about the immense difficulties affecting its elimination (31).

Another important matter is that alcohol consumption is frankly forbidden in Islam. Low alcohol use rates and very high rates of abstention can be found in regions representing populations of the Islamic faith (32). A glance to the documented data indicates the low alcoholism rate (2\%) in Iran (33) (F1). This is why although there are many poetic literary texts in favor of alcohol and wine in Persian literature, almost all of the Iranian readers ab- 
stract other meanings such as "love", "pure", "clear", "life cherishing" and "animating" from the words "alcohol" and "wine". While we see such abstraction from the word "opium", which is not directly forbidden in the Qur'an, the holy book of Islam, as well as the Hadith (F2) and Sunnah (F3) rarely. Here are some examples of alcoholic beverage consumption in famous authorities of Persian poetic literature:

"With wine, bicolor the prayer-mat if the Pir of the Magians (F4) bid thee;

For the way and usage of the stages not without knowledge is the holy traveler" (34).

"Saki (F5)! Give the wine remaining; for, in Paradise, thou wilt not have

The bank of the water of the Ruknabad (F6) nor the rose of the garden of Musalla (F7)" (34).

"O moon-like beauty! Drink wine in the moonlight, for

Oft this moon will shine down on earth and will not find us" (18).

"Bring a pot of wine and let us drink together,

Before pots are made from our dust." (18).

"Saki bring my wine as I repented abstinence;

Minstrel play something for me as I scorn repentance" (35).

"Once again I have a hangover from the last night's wine

From the garden of union with the beloved I have a rose at my side" (35).

Perhaps, the position of raw opium in the Iranian herbal and traditional medicine contributes to the attitude formation of Iranian people regarding opium too. This substance is recommended in some ancient medical books for therapeutic proposes. Opium was a part of Roman collection which the pharmacists always used to load it in drug components. Unfortunately we see that there is no negative attitude regarding opium in many traditional physicians, as well as in some modern doctors.

Regarding this superstitious common belief, drug control headquarters should focus on education and correction of the faulty unhealthy attitude toward opium consumption. They should consider the religious beliefs of the general population in their educations. Religious authorities who have a good potential to lead the demos should play a more active role in this field. I believe that the Islamic doctrine has discouraged any intoxicant and slanderer substance. Regarding this doctrine, general public should avoid any material which is harmful and damage the body. Since the Holy Quran says, "Do not expose yourselves to ruin through your own hands" (36), and violence against oneself is prohibited by the Hadith (37). The psychoeducational interventions should comprise physicians as well. Considering the scientific findings in modern and traditional medicine in the medical students' curriculum and in the physicians retraining programs is another important topic.

Besides, future research is warranted to investigate the effect of psychoeducational interventions in both the opium consumption rate of general population, as well as the successfulness of opium abuse/dependence treat- ment programs. The focus of psychoeducational efforts should be addressed to medical and psychiatric patients, who are supposed to be more eager to self-medication and opium consumption.

\section{Footnotes:}

(F1). Regional increases in consumption being reported in the WHO South-East Asia Region (33), and recent prevalence of recreational alcohol consumption (more than $10 \%$ in young men in some regions of Iran) (38) needs another explanation at another time.

(F2). Hadith in Islamic religious use is often translated as "prophetic traditions", meaning the corpus of the reports of the teachings, deeds and sayings of the Islamic prophet Muhammad (39).

(F3). Sunnah is the way of life prescribed as normative for Muslims on the basis of the teachings and practices of the Islamic prophet Muhammad and interpretations of the Quran (40).

(F4). "Pir of the Magians" means elder or experienced person of the bar (17).

(F5). Saki means "butler" (17).

(F6). Ruknabad is a famous river in Shiraz (17).

(F7). Musalla is the name for an open space outside a mosque that is mainly used for praying (41).

\section{Acknowledgements}

The author would like to appreciate the valuable comments of Dr. Emran Mohammad Razzaghi and Dr. Seyyed Taha Yahyavi on the earlier draft of this article.

\section{Declaration of Interest}

None declared.

\section{References}

1. Ahmad DL. Opium smoking, anti-Chinese attitudes, and the American medical community, 1850-1890. American Nineteenth Century History. 2000;1(2):53-68.

2. Cannabis, Coca, and Poppy: Nature's Addictive Plants. Arlington: DEA Museum \& Visitors Center; Available from: http://www.deamuseum. org/ccp/resources/index.html\#opium.

3. United Nations Group of Experts, editor. Geographical Names Working Paper No. 61,.; United Nations Group of Experts on Geographical Names Working Paper No. 61, 23rd Session.; 2006; Vienna.

4. Durant W. Our oriental heritage (part 1 of the story of civilization). New York NY: Simon and Schuster; 1988.

5. Wikipedia . History of Iran.. Available from: http://en.wikipedia. org/wiki/History_of_Iran.

6. Carlson ET, Simpson MM. Opium as a tranquilizer. Am J Psychiatry. 1963;120:112-7.

7. Iranian philosophers: al-Razi.: the Window (philosophy of the interest);. Available from: http://www.trincoll.edu/depts/phil/ philo/phils/muslim/razi.html.

8. Avicenna.. Available from: http://ahmadbabai.blogfa.com/post/56.

9. Christensen JB. Drugs, deviancy and democracy in Iran: The interaction of state and civil society.New York: IB Tauris; 2011.

10. Zarghami M. Is Methadone Substitution the Best Treatment of Choice for Opioid Dependence? Iranian Journal of Psychiatry and Behavioral Sciences. 2008;2(2):1-4.

11. UNODC . World Drug Report New York: United Nations Office on 
Drugs and Crime; 2011.

12. The Guardian. Iran faces up to its most lethal threat/drugs.United Kingdon; 2005.

13. United Nations World Drug Report 2010 and Iran: payvand; 2010.

14. Razzaghi EM, Rahimi-Movaghar A, Hosseini M, Madani S, Chatterjee A. Rapid Situation Assessment of Drug Abuse in Iran Tehran: Iranian Welfare Organization and UNDCP.1999.Tehran: Iranian Welfare Organization and UNDCP; 1999.

15. Iranian Ministry of Health and Medical Education. Tehran: 2000. Statistics on Drug abuse in Iran.

16. Pashaei T, Moeeni M, Roshanaei Moghdam B, Heydari H, Turner NE, Razaghi EM. Predictors of treatment retention in a major methadone maintenance treatment program in iran: a survival analysis. J Res Health Sci. 2014;14(4):291-5.

17. Dehkhoda A. Encyclopedia Dictionary. Moin M, Shahidi J editors. Tehran: Tehran University Publication; 1998.

18. Kuhestany K. Khayyam O. Quatrains.Tehran: Iranian society; 2006.

19. Rahimi N, Gozashti MH, Najafipour H, Shokoohi M, Marefati H. Potential effect of opium consumption on controlling diabetes and some cardiovascular risk factors in diabetic patients. Addict Health. 2014;6(1-2):1-6.

20. [incorrect beliefs on drugs]. Proceedings of the National Congress on Addiction; Challenges, Treatments. 2002 Zanjan, Iran..

21. Zargham M, Khalilian AR, Tajic Jalayeri H, Khadivi Sohrabi S, editors. [Study of frequency, situation and beliefs on opium consumtion in the elderly].; Proceedings of the National Congress on Addiction.; 2002; Zanjan, Iran.

22. Sadr SS, Mahmoudinia SAR. Frequency of opium use among diabetic patients and their attitude. Iranian Journal of Psychiatry and Behavioral Sciences. 2009;3(2):33-8.

23. Fatemi SS, Hasanzadeh M, Arghami A, Sargolzaee MR. Lipid Profile Comparison between Opium Addicts and Non-Addicts. J Tehran Univ Heart Cent. 2008;3(3):169-72.

24. Shirani S, Shakiba M, Soleymanzadeh M, Esfandbod M. Can opium abuse be a risk factor for carotid stenosis in patients who are candidates for coronary artery bypass grafting? Cardiol $\mathrm{J}$. 2010;17(3):254-8.

25. Sadeghian S, Boroumand MA, Sotoudeh-Anvari M, Rabbani S, Sheikhfathollahi M, Abbasi A. Effect of opium on glucose metabolism and lipid profiles in rats with streptozotocin-induced diabetes. Endokrynol Pol. 2009;60(4):258-62.
26. Azod L, Rashidi M, Afkhami-Ardekani M, Kiani G, Khoshkam F Effect of opium addiction on diabetes. Am J Drug Alcohol Abuse. 2008;34(4):383-8.

27. Asgary S, Sarrafzadegan N, Naderi GA, Rozbehani R. Effect of opium addiction on new and traditional cardiovascular risk factors: do duration of addiction and route of administration matter? Lipids Health Dis. 2008;7:42.

28. Rezvanfar MR, Farahany H, Rafiee M, Kaboli S. Opium consumption challenge and diabetes mellitus control. Iranian Journal of Diabetes and Obesity. 2011;3(2):72-6.

29. Karam GA, Reisi M, Kaseb AA, Khaksari M, Mohammadi A, Mahmoodi M. Effects of opium addiction on some serum factors in addicts with non-insulin-dependent diabetes mellitus. Addict Biol. 2004;9(1):53-8.

30. Mohammadi A, Darabi M, Nasry M, Saabet-Jahromi MJ, MalekPour-Afshar R, Sheibani H. Effect of opium addiction on lipid profile and atherosclerosis formation in hypercholesterolemic rabbits. Exp Toxicol Pathol. 2009;61(2):145-9.

31. Alfred WM. Opium History Up To 1858 A.D.. Available from: http:|| www.opioids.com/opium/history.

32. World Health Organization Global status report on alcohol and health. 2011.

33. WHO . Global status report on alcohol and health. In: World Health Organization, editor. Geneva: 2014.

34. Kuhestany K, editor. Ghazals of Hafez. Tehran: Iranian society; 2007.

35. A selection of Sa'di's Ghazals.Tehran: Mirdashti Farhangsara and Zeighami Publishers; 1999.

36. Irving TB. The Holy Qurān. Text: translation and commentary.Tehran: Suhravardi Research and Publication Center; 2003.

37. Rahman F. Islam and health/medicine: a historical perspective In: Sullivan LE editor. Healing and Restoring-Health and Medicine in the World's Religious Traditions, Macmillan.; 1986.

38. Lankarani KB, Afshari R. Alcohol consumption in Iran. Lancet. 2014;384(9958):1927-8.

39. Wikipedia . Sunnah.. Available from: http://en.wikipedia.org/ wiki/Hadith.

40. Wikipedia.Hadith.. Available from: http://en.wikipedia.org/wiki/ Sunnah.

41. Brill L.The Encyclopaedia of Islam.Kuwait:al-mausua al-fiqhiyya;1998. 